A CONVENIENT SYNTHESIS OF $\underline{\mathbf{s}}^{-}\left(5^{\prime}-\right.$ DEOXY $-5^{\prime}-$ ADENOSYL $)-$

\title{
$( \pm)$-2-METHYLHOMOCYSTEINE
}

Kondareddiar Ramalingam and Ronald $w$. Woodard* Department of Medicinal Chemistry, College of Pharmacy, University of Michigan, Ann Arbor, Michigan 48109-1065

Abstract. The synthesis of $\underline{\mathbf{s}}-\left(5^{\prime}-\right.$ deoxy-5'-adenosyl $)-( \pm)-2$-methylhomocysteine in two steps from $( \pm)$-2-methylmethionine is described.

Modification of the purine ring, sugar, and amino acid portions of s-adenosylhomocysteine (SAH) and -adenosylmethionine (SAM) have furnished a number of new inhibitors of transmethylase enzymes $^{1-5}$ as well as inhibitors for enzymes involved in polyamine biosynthesis. ${ }^{6-8}$ The replacement the of methine proton of the $\alpha$-amino acid carbon with a methyl group is of considerable interest for the inhibition of SAM decarboxylase, ${ }^{9}$ an essential enzyme in the blosynthesis of the polyamines spermidine and spermine. Previous synthesis ${ }^{6}$ of the title compound has involved five steps and the use of rather noxious chemicals, and was obtained in only 30 overall yield.

We now wish to describe a two-step one-pot synthesis of $\underline{s}^{-}\left(5^{\prime}-\right.$ deoxy-5'-adenosyl)-( $\left.t\right)-2$-methy 1homocysteine. For our synthesis we elected to start with $( \pm)-2$-methylmethionine. ${ }^{10}$

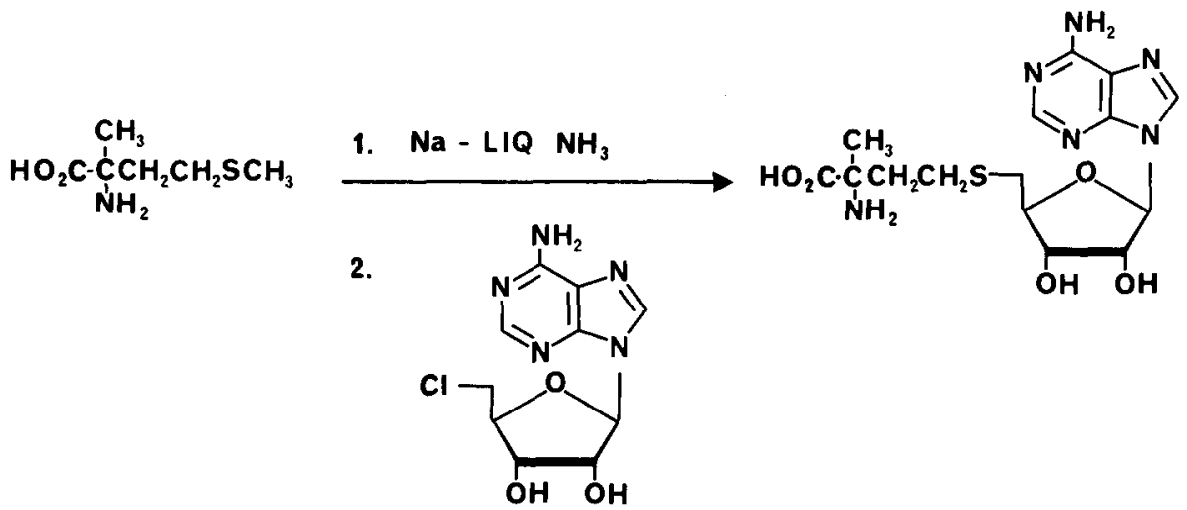

Although not presently comercially available, (+)- and (-)-2-methylmethlonine are avallable by facile synthetic routes. 11 we found that sodium in liquid ammonia would effect the cleavage of the methyl group of methionine to form the sodium salt of homocysteine. 12 For this reaction to occur, a slight excess of sodium was added to liquid ammonia containing (t)-2-methylmethionine at $-40^{\circ} \mathrm{C}$. The reaction mixture was held at $-40^{\circ} \mathrm{C}$ for $0.5 \mathrm{~h}$ and $5^{\prime}$-chloro-5'-deoxyadenosine ${ }^{13}$ was added in one portion. Stirring at $-40^{\circ} \mathrm{C}$ was continued for 6 h. The ammonia was allowed to evaporate over a 20 to 30 min period and the residue was 
dissolved in water and heated to reflux $(4 \mathrm{~h})$. After the reaction mixture was cooled and the $\mathrm{pH}$ adjusted to $6.5(\mathrm{NN} \mathrm{HCl})$ the solution was applied to a column of Dowex 50x4-200, $\mathrm{NH}_{4}^{+}$form. After elution with water $(150 \mathrm{ml})$, the column was washed with $1 \mathrm{~N} \mathrm{NH}_{4} \mathrm{OH}$ to obtain the desired product which was lyophilized. The crude product was purified via silica gel chromatography by elution with butanol-acetic acid-water $(13: 2: 5)$ to remove unreacted $5^{\prime}$-chloro-5'-deoxyadenosine. Any traces of acetic acid were removed on a small Dowex $50 \times 4-200\left(\mathrm{NH}_{4}^{+}\right)$ion exhange column. The ninhydrin positive fractions were combined and freeze-dried to give a white solid in $55 \%$ yield, mp $249-250^{\circ} \mathrm{C}$ dec. $\left(1\right.$ it. ${ }^{6} 243^{\circ} \mathrm{C}$ dec.). ${ }^{14}$

The application of this facile synthesis of amino acid modifled SAH and SAM derivatives is under further investigation in our laboratory.

\section{References}

1. V. N. Rekunova; I. P. Rudakova; A. M. Yurkevick, Tetrahedron Lett., 2811, (1973).

2. J. K. Coward; D. L. Bussolotti; C. D. Chang, J. Med. Chem., 17, 1286, (1974).

3. R. T. Borchardt; J. A. Huber; Y.S. Wu, J. Med. Chem., 19, 1004, (1976).

4. R. T. Borchardt, J. Med. Chem., 23, 347, (1980).

5. T. Itoh; T. Sugaware; Y. Mizuno, Nucleosides and Nucleotides, $1,179,(1982)$.

6. M. C. Pankaske; M. M. Abdel-Monem; A. Raina; T. Wang; J. E. Foker, J. Med. Chem., 23, 121. (1980).

7. J. K. Coward; N. C. Motola; J. D. Moyer, J. Med. Chem., 20, 500, (1977).

8. H. Hibasamf; R. T. Borchardt; S. Y. Chen; J. K. Coward; A. E. Pegg, Biochem. J., 187. 419. (1980).

9. M. Pankaskie: M. M. Abdel-Monem, J. Med. Chem., 23, 121, (1980).

10. Available from Aldrich Chemical Co. or sigma Chemical co.

11. U. Schollkopf; R. Lonsky, Synthesis, 675, (1983).

12. D. Dolphin, K. Endo, Analyt. Biochemistry, 36, 338, (1970).

13. K. Kikugawa; M. Ichino, Tetrahedron Lett., 87, (1971).

14. $l_{\mathrm{H}-\mathrm{NMR}}\left(\mathrm{D}_{2} \mathrm{O}\right) \delta 8.36\left(\mathrm{~s}, 1 \mathrm{H}, \mathrm{C}_{8}-\mathrm{H}\right), 8.20\left(\mathrm{~s}, 1 \mathrm{H}, \mathrm{C}_{2}-\mathrm{H}\right), 6.10\left(\mathrm{~d}, \mathrm{~J}=4.5 \mathrm{~Hz}, 1 \mathrm{H}, \mathrm{C}_{1},-\mathrm{H}\right), 4.88(\mathrm{t}, \mathrm{J}=5,0 \mathrm{~Hz}, 1 \mathrm{H}$. $\left.C_{2},-H\right), \quad 4.48\left(t, J=5.0,1 H, C_{3},-H\right), 4.44\left(m, 1 H, C_{4},-H\right), 3.11\left(m, 2 H, C_{5},-H\right), 2.76\left(m, 2 H, C_{\gamma}-H\right), 2.22(m$, $\left.2 \mathrm{H}, \mathrm{C}_{\beta}-\mathrm{H}\right), 1.52$ and $1.46\left(2 \mathrm{~s}, 3 \mathrm{H},-\mathrm{CH}_{3}\right)$.

Acknowledgment: This work was supported by U. S. Public Health Service Grant GM 30097.

(Received in USA 26 November 1984) 